\title{
Fisheries and water productivity in tropical river basins: enhancing food security and livelihoods by managing water for fish
}

\author{
Patrick Dugan ${ }^{1}$, Madan Dey $^{2}$ and V. V. Sugunan ${ }^{3}$ \\ ${ }^{1}$ WorldFish Center, Africa and West Asia Office, $6{ }^{\text {th }}$ Floor, 3 Abu El Feda Street, Zamalek Cairo, Egypt \\ ${ }^{2}$ WorldFish Center, Jalan Batu Maung, Batu Maung, PO Box 500 GPO 10670 Penang Malaysia \\ ${ }^{3}$ Challenge Program on Water and Food, $6^{\text {th }}$ Floor, 3 Abu El Feda Street, Zamalek Cairo, Egypt
}

\begin{abstract}
Faced with growing pressure upon freshwater resources, increased water productivity in agriculture is essential. Efforts to do so however need to consider the wider role of water in sustaining food production. This paper considers the importance of water management in sustaining fish production in tropical river basins, and the potential for enhancing food production and income to farmers by integrating fish production into some farming systems. Specific examples from selected river systems and irrigated farming systems in Africa and Asia are provided. These highlight the benefits of integrating the water requirements for fish into water allocation decisions. In some cases these benefits can be realised without any reduction in the water available for other purposes, while in others a trade-off needs to be considered. The nature of these trade-offs needs to be better understood for better decision making in water management.
\end{abstract}

\section{Media summary}

Fish is an important food crop, and the water requirements of fisheries need to be factored into water management decisions. Examples of how this can be done through win-win approaches for fisheries and other water uses are provided.

\section{Key Words}

Fish, Fisheries, Aquaculture, Rivers,

\section{Introduction}

The past decade has seen growing recognition of the crisis facing the world's water resources and the need for concerted action to use these more efficiently. In this context the work of national and international agricultural research centres to improve water productivity in crop agriculture is of immense importance. In moving forward to develop the technological and institutional innovations required to achieve this, it is however essential to ensure that the wider role of water in supporting food production and sustaining household incomes is recognised, and the water requirements to sustain this incorporated fully into water management decisions. Foremost amongst these concerns is the role of water in sustaining fish production, the principal source of animal protein and income to large numbers of lowincome families in Africa, Asia and Latin America. The present paper examines these concerns and reviews approaches to improving food production by incorporating fish into water management from basin to farm levels.

Freshwater fish - the protein of the poor

Over large parts of Africa, Asia and Latin America, freshwater fisheries are a crucially important resource for poor rural families. Rich in protein and minerals, fish are a high-value food. Many are also rich in healthy unsaturated fatty acids that play an important role in the development of bones, nervous system, and brain in children. Most small fish are eaten whole and contribute significantly to calcium intake. Teutcher (2001) reports that small whole fish tend to contribute far more to dietary balance than do prepared portions of larger fish.

In contrast to the marine fisheries of developing countries, most of which are the focus of a technology intensive multi-million dollar international industry, the majority of inland freshwater fisheries are harvested using a range of comparatively simple, low-cost, technologies ranging from traps to clasp nets and spears. In this way, these resources are widely available to millions of people, including to women and children who frequently harvest small but nutritionally important quantities (Thilsted et al., 1997, 
Thilsted and Roos, 1999) in ponds, streams and marshes within easy reach of their homes (SverdrupJensen, 1999).

Rivers and their associated floodplains are particularly important in sustaining those fish harvests and correspondingly play a central role in sustaining livelihoods and providing high quality nutrition. For example in Cambodia fish, harvested primarily from the Mekong river system, constitute $65-75 \%$ of total protein in the diet (Guttman, 1999) and the value of the catch is between US\$ 150-200 million yearly (Van Zalinge et al, 2000). The total direct use value of the fishery resources of the Lower Mekong Basin has been estimated as US\$ 1478 million (Sverdrup-Jensen 2002). In Bangladesh fish contribute $60 \%$ of the intake of animal protein, and inland fisheries contribute some $42 \%$ of the total fish catch. In inland rural areas about $80 \%$ of households catch some fish each year, either for their own consumption or for sale (Williams, 1999).

\section{Water requirements for river fisheries}

As demand for water for agricultural, industrial and domestic needs has increased, river flows have been reduced. Today a growing number of rivers run dry along part of their course for all or part of the year, including the Colorado (USA and Mexico) and the Huang Ho (China). While use of river water to meet these needs has brought enormous benefits in many cases, it has also brought costs. Looking forward to the next 25 years, it is important that the future management of water brings benefits to agriculture while sustaining food production from fisheries.

Production from river fisheries is influenced by a number of parameters of which the most important are water level, duration of the flood, timing of the flood, regulation of flooding, characteristics of the flooded zone, migration routes, and dry season refuges (Welcomme, 1985; Baran and Cain, 2001). Of these the first four are functions of the flooding regime and are therefore particularly vulnerable to changes in flow that result from water allocation decisions within the river basin. Reduced water levels also exacerbate problems of pollution and eutrophication, especially in floodplain water bodies, which rapidly become anoxic in highly eutrophic conditions.

Using data from the Niger, Shire and Kafue rivers of Africa, Welcomme (1985) has examined the relationship between river flow and fish production in some detail and shown that it is possible to predict catches in river systems from regression analyses of the past performance of the fishery. This work has been further developed for the Niger by Lae (1992). More recently Baran et al (2001a) have modelled the flow-catch relationship for the Dai (large stationary trawl nets fixed in the river) fishery on the Tonle Sap lake/floodplain system of the Mekong where there is a strong correlation between water level and the annual Dai catches. As the catch estimate for the Dai fishery in Tonle Sap at a particular period of time varies considerably, Baran et al (2001a) estimated this relationship using three sets of catch estimates (Fig 1).

From the highest production of 20,000 tonnes, a drop of every $1 \mathrm{~m}$ in flow predicts a loss of approximately 2500 tonnes at high flood levels rising to 5000 tonnes at low water levels (Fig 1).

However while these analyses from a range of river systems illustrate the importance of river flow for sustaining river fisheries, they provide only part of the information required to manage rivers for sustained fisheries production. In each case only the portion of the fishery with the best available data has been examined. While in the case of the Niger this focuses upon the inner delta and a substantial part of the recorded catch along the river, the analysis can only provide management guidance for the inner delta. In the case of the Mekong the Dai fishery is only a small component of the system. The model illustrated in Fig. 1 may therefore be used to identify the specific flow requirements for that fishery, but can serve only as a very partial indicator for the larger Mekong fishery. 


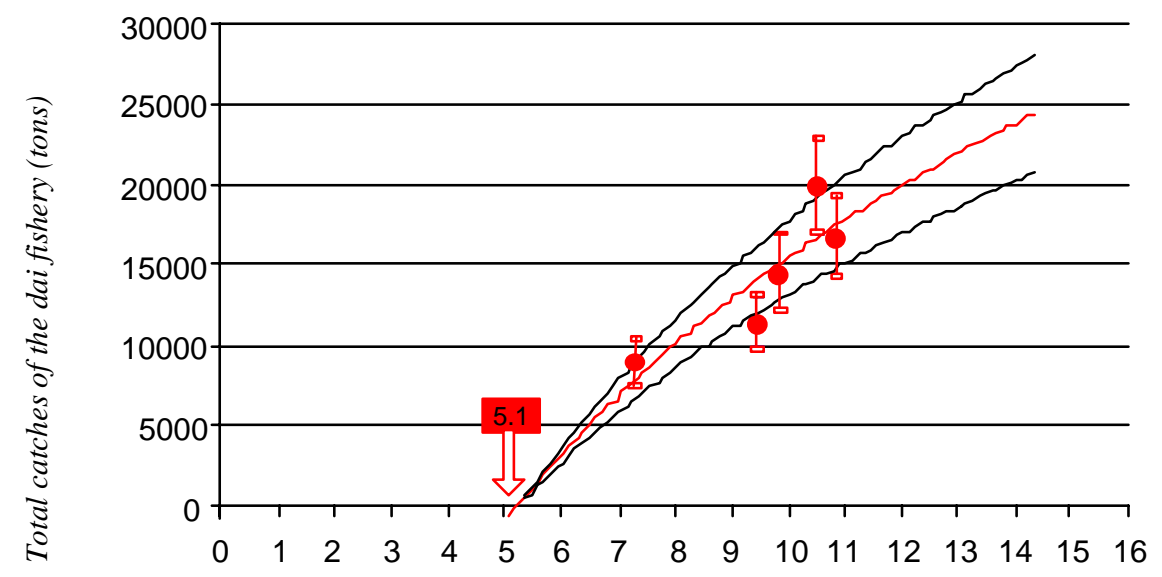

Average October water level in the Tonle Sap River (Kampong Chhnang gauge, meters)

Figure 1: Relationship between annual Dai catches and average water level in October in the Tonle Sap River (logarithmic regression1) (Baran et al., 2001a)

Even for the Niger, where Welcomme (2001) concluded that at least 14 years of data are required to accurately predict catch from flood levels, this is conditional upon there being no major changes to the resource base through overfishing, environmental change and other factors. In light of the pressures upon these river systems from a diversity of sources, and those upon the communities who use them, this condition is rarely met today.

In addition, while the biological basis of these flood-fishery relationships holds true in broad terms in different river systems (Welcomme, 1985, 2001), the detailed nature of that relationship and the consequent response of the fishery to changes in flooding and other factors varies from river to river. For this reason detailed studies from one river system are at present of little value in providing specific guidance on how to sustain or improve productivity in other river basins.

In recognition of these constraints increasing attention is being devoted to the development of decisionsupport tools that integrate recent advantages in modelling of river fisheries with contemporary methodologies for assessing environmental flows. A recent review of these environmental flow methodologies, fisheries production models, and Bayesian risk assessment approaches (Arthington et al., in press) has emphasised the importance of moving towards the development of scenarios that can be used by river-basin authorities, and water and fisheries managers, to predict the impact of changes in water flow upon fisheries and other in-stream resources, and the livelihoods dependent upon them.

After examining the strengths and deficiencies of a comprehensive group of holistic environmental flow methodologies Arthington et al identified the DRIFT (Downstream Response to Imposed Flow Transformations) methodology as the most amenable to integration of specific fisheries modelling tools. Following on from this analysis research is now needed to integrate these different modelling approaches into a single framework model for tropical river fisheries that will allow specialists to select the appropriate components, models and parameters depending on where they are situated in a river system, and on the available data. Such research is now being designed for several rivers in Africa.

As this work develops it needs to be pursued in conjunction with efforts to strengthen and provide information in support of governance systems for these river systems. Without such engagement, including effective interaction with concerned community organisations, information on water-fish dynamics is of limited practical value for improving food security and livelihoods. Future work needs to be designed and managed in a manner that will address these concerns.

1 Baran et al. (2001b) showed that the most appropriate fit was not a linear but a logarithmic relationship. As biological responses to environmental variations are not linear but asymptotic, the logarithmic curve better illustrates such responses. 


\section{Integrating fish into irrigation systems}

Irrigated agriculture is the largest user of the world's fresh water (Seckler et al, 1998), producing one third of the world's food from 240 million ha, 17\% of the world's cropland (Oi, 1997). As efforts to enhance water productivity in agriculture increase, one option is to enhance the production and harvest of fish from irrigation systems, so increasing the overall food production without increasing water use.

At present, no comprehensive assessment of the value of fisheries in irrigation systems exists. However fish have been harvested in irrigation systems for at least two millennia (Fernando and Halwart, 2000) and a variety of studies show that these continue to yield substantial fish harvests (Ruddle and Zhang, 1988; Haylor, 1994). Yet as argued by Fernando and Halwart (2000), the current use of irrigation systems for fish production falls far short of potential.

The canals and channels associated with irrigation systems are a particularly promising option for further development. Redding and Midlen (1991) calculate that $2.5 \mathrm{~km}$ of larger canals and $10 \mathrm{~km}$ of smaller channels are created for every 1000ha irrigated. Using the figure of 240 million ha this gives an estimate of $600,000 \mathrm{~km}$ of larger channels and 2.4 million $\mathrm{km}$ of small channels. While there are no systematic data on the proportion of these irrigation systems that are used for fish production, nor for current or potential harvests, studies reviewed by Redding and Midlen provide an indication of the range of yields from capture fisheries and cage and pen culture (Table 1). On the basis of this review Redding and Midlen conclude that while there is potential for the management of irrigation canals as capture fisheries, the greatest potential lies with cage and pen culture. They argue that use of pens and cages for fish culture could substantially increase the efficiency of water use in irrigation systems.

\begin{tabular}{lll}
\hline Location & Yield & Source \\
\hline Capture Fisheries & & \\
Gezira, Sudan & $50-2786 \mathrm{~kg} / \mathrm{ha}$ (mean $660 \mathrm{~kg} / \mathrm{ha})$ & Coates, 1984 \\
USSR & $50-100 \mathrm{~kg} / \mathrm{ha}$ & Chiznik, 1969 \\
Bangladesh & $500 \mathrm{~kg} / \mathrm{ha}$ & Marr, 1986 \\
Thailand & $350 \mathrm{~kg} / \mathrm{ha}$ & Swingle, 1972 \\
Cages and Pens & & \\
Indonesia & $50 \mathrm{t} / \mathrm{ha}$ & Costa Pierce and Effendi, 1988 \\
Egypt & $100 \mathrm{t} / \mathrm{ha}$ & Ishak, 1982; Ishak et al, 1986 \\
China & $300-1350 \mathrm{~kg} / \mathrm{ha}$ & \\
\hline
\end{tabular}

Table 1. Annual yields from capture fisheries and from cage and pen culture in irrigation canals (after review by Redding and Midlen, 1990)

Reservoirs are an essential component of most irrigation systems and, together with those built for flood control and power generation purposes cover a vast area worldwide. The 60,000 largest reservoirs those with a volume of 10 million cubic meters - are estimated to cover a surface of about $400,000 \mathrm{~km}^{2}$ and together hold some $6500 \mathrm{~km}^{2}$ (Miranda, 2000), while there are many hundreds of thousands of small ones. In eastern and southern Africa alone there are estimated to be between 50-100,000 small water bodies (Haight, 1994).

This large area and volume of reservoirs plays an important role in global fisheries (Moreau and DeSilva, 1991; Petrere, 1996; Fernando et al, 1998; Miranda, 1999), and there is considerable potential remaining. Culture-based fisheries of small reservoirs can augment fish yield in a substantial way as they did in China (743 kg/ha, De Silva, 2001), and contribute to almost the entire inland fish production in small island developing nations like Sri Lanka (300 kg /ha; Pet, 1995) and Cuba (125 kg/ha). In Cuba, fish produced from small reservoirs is the main source of freshwater fish supply and provides an essential source of animal protein (Sugunan, 1997). However, in many countries, this resource remains underutilized as in India where the average yield from more than 19,000 small reservoirs (1.5 million ha) is less than $50 \mathrm{~kg} / \mathrm{ha}$ and the all reservoirs (3 million ha) produce less than $20 \mathrm{~kg} / \mathrm{ha}$ (Sugunan, 2001). In Asia potential yields from reservoir fisheries are estimated to be $500-2000 \mathrm{~kg} / \mathrm{ha} / \mathrm{year}$ (De Silva and Amarasinghe, 1996), while the use of "cove culture" in the water inlets to reservoirs in China brings productivity in these areas up to the level of pond aquaculture, approximately $4500-5000 \mathrm{~kg} / \mathrm{ha}$.

Advances of this sort coupled with enhanced stocking regimes are expected to enhance productivity from these systems and a range of small water bodies in the future (ICLARM, 1999). 
In addition to stock enhancement and other measures to enhance capture fisheries cage culture is also used to increase production in reservoirs. First developed in China cage culture is now used in an increasing number of countries where it is seen as a means of increasing aquaculture potential without using scarce land resources, and as a means of compensating for loss of agricultural land under hydro dams. For example in the Saguling and Cirata hydropower reservoirs in West Java cage aquaculture activities employed some 7000 people, produced 25,000 metric tons, and generated a gross revenue of US\$24million, over twice the estimated annual revenue from the rice fields lost to the reservoirs (CostaPierce, 1998). The extent to which these results can be replicated in other areas is not known. In addition serious problems were encountered with eutrophication from the cages and this will be a concern in other areas. For long-term sustainability of these systems strict adherence to guidelines regulating culture densities and water quality is required (Welcomme, 2001).

\section{Rice-fish culture}

There is an estimated 81 million ha of irrigated rice worldwide, with an additional 11 million ha of flood prone land under rice cultivation (Halwart, 1998). Rice-fish production is possible in both of these systems under either capture systems where wild fish enter, reproduce and are harvested from the flooded fields, or culture systems where the rice fields are stocked with fish either simultaneously or alternately with the rice crop. One and sometimes both of these systems are practised in many countries (Table 2). While Asian countries like China, Bangladesh, India, Malaysia, Indonesia, Thailand and Vietnam have a long history of integrated agri-aquaculture systems, the concept is relatively new to Africa. But, today, this farming system is fast becoming a favourite option among the resource-poor fish farmers in the developing world, mainly because of its ability to remove many risks associated with the stand-alone pond aquaculture of both intensive or extensive scale (Prein, 2002).

\begin{tabular}{llll}
\hline Country (year) & Area of rice-fish (ha) & Yield $(\mathrm{kg} / \mathrm{ha})$ per year? & Total production (tons) \\
\hline China (1996) & 1.2 million & 3,183 & 377,000 \\
Egypt (1995) & 172,600 & 115 & 19,863 \\
Indonesia (1985) & 94,309 & 670 & 63,187 \\
Thailand & 3.1 million & 25 & 77,500 \\
Vietnam & 40,000 & na & na \\
\hline
\end{tabular}

Table 2. Leading countries in rice-fish production (derived from Halwart, 1998, and GAFRD, 2000)

These fish harvests add significantly to the return obtained by farmers. For example in Cambodia, Guttman (1999) reports that the value of fish caught in rice fields reaches $37-42 \%$ of that of rice production. In addition however the culture of fish within rice fields can increase rice yields, especially on poorer soils and in unfertilized crops where the fertilizing effect of fish is greatest. Improvement in income level attributable to rice fish interaction in seven countries has been summarized by Demaine and Hatwart (2001) (Table 3). Brummett (2002) reports six times as much cash as typically generated by Malawian small farmers resulting in three times higher net income than staple maize crop and homestead combined. In his review of trends in rice-fish farming Halwart (1998) reports that together with savings of pesticides and earnings from fish sales, these increased yields result in net incomes that are 7-65\% higher than for rice monoculture. In more recent work the WorldFish Center has recorded a $10 \%$ lower cost of production for rice in flood-prone rice ecosystems in Bangladesh and Vietnam and a higher net return from rice fish of an additional 400US\$/ha (Bangladesh), 340 US\$/ha Red river delta (Vietnam), and 220 US\$/ha in Mekong delta (Vietnam). Significantly these benefits were obtained with no reduction in the wild fish catch (Dey and Prein 2003, 2004a, 2004b). 
Table 3. Selected economic indicators of rice and rice-fish farming

\begin{tabular}{|c|c|c|}
\hline Indicator & Country & $\begin{array}{l}\text { Chang } \\
(\%)\end{array}$ \\
\hline $\begin{array}{l}\text { Increase in rice yield } \\
\text { equivalent }\end{array}$ & Indonesia & +20 \\
\hline $\begin{array}{l}\text { Income from fish as per } \\
\text { cent of total farm } \\
\text { income }\end{array}$ & Malaysia & $+7 \&$ \\
\hline Net return & Philippines & +40 \\
\hline Net return & China & +45 \\
\hline Net farm income & Thailand & $\begin{array}{l}+18 \& \\
+35\end{array}$ \\
\hline $\begin{array}{l}\text { Cases with net return } \\
\text { higher than rice } \\
\text { monoculture }\end{array}$ & Thailand & +65 \\
\hline Net benefit & Thailand & +80 \\
\hline Net profit & Bangladesh & $\begin{array}{l}+64 \& \\
+95\end{array}$ \\
\hline Total farm cash return & Vietnam & +69 \\
\hline & Vietnam & 0 \\
\hline
\end{tabular}

Source: Demaine and Halwart, 2001

\section{Comments}

Research Station results, fish yield expressed in rice equivalent

Figures for owners and tenants respectively in double rice cropping area

\begin{abstract}
Summary of results from nation-wide field trials during the late 1970 s to 1987 in irrigated rice areas

Results from four farm households in Hubei Province

Figures for Research station and farer field respectively

Difference in rice yield equivalents
\end{abstract}

20 out of 25 farms had higher net returns from rice-fish farming than from rice monoculture

Net benefits are higher in the aman or wet season and lower in boro or dry season

$20 \%$ of the trench construction costs considered in capital costs. Operating costs increased by $83 \%$ for labor and $100 \%$ for irrigation, but had savings in the use of pesticides Mekong delta, beneficial and net effects thought to be related to environmental sustainability, system biodiversity farm diversification and household nutrition

Small-scale integrated farming systems are more efficient at converting feeds into fish and these produce fewer negative impacts than purely commercial fish farms. Brummett (2002) illustrates that culturing tilapia in $1 \mathrm{~m}^{2}$ cage system involved 21,700 $\mathrm{m}^{2}$ ecological footprint $\left(6 \mathrm{~g}\right.$ of fish produced per $\mathrm{m}^{2}$ of footprint) while the corresponding figures for supporting a $1 \mathrm{~m}^{2}$ water fed integrated fish pond for raising tilapia was $1.8 \mathrm{~m}^{2}$ (264 $\mathrm{g}$ of fish produced per $\mathrm{m}^{2}$ of footprint)

It is clear from this analysis that there are many options for enhancing food production from fish in managed aquatic systems. However the most appropriate technology will vary from country to country and site to site. In addition the social and economic conditions under which these technologies can be pursued needs to be understood. Recent studies in Vietnam and Bangladesh show that socially viable approaches for integrating fish into rice culture systems are possible, but much more work is needed to understand the wider application of these approaches and to understand the social and economic viability of much of the intensive culture options such as cage culture in irrigation canals and reservoirs. Similarly the governance arrangement for capture fisheries in irrigation canals also require detailed analysis if the full social value of these resources is to be harnessed.

\section{Aquaculture}

Superficial consideration of the water requirements for aquaculture suggests that it is a water intensive means of food production. However even when the water requirements for feed production and pond maintenance are included Brummett (1997) has calculated that culture of channel catfish (Ictalurus punctatus), and tilapias (family Cichlidae) requires less water than that required to produce broiler chickens (Pimentel et al., 1997). The figures provided by Brummett of 3350 liters of water required for each kilogram of catfish produced, and 2800 liters for each kilogram of tilapia are based on well-managed ponds, and water requirements will clearly be greater in many instances. However this initial analysis suggests that much more rigorous analysis of the water economics of pond aquaculture is merited.

Intensive aquaculture systems also provide the possibility of using the nutrient rich pond water for irrigation, and a growing number of studies have demonstrated that substantial benefits can be obtained by combining intensive aquaculture with irrigated crop production in this way (Bondari et al 1983; D `Silva and Maughan, 1994, 1996; McMurty et al., 1997). While the full operational viability of such 
schemes needs to be tested in an appropriate range of on-farm conditions, a growing number of systems are now being developed in West Asia and North Africa, notably in Kuwait (Cruz et al., 2000), Saudi Arabia, and Egypt where water for pond aquaculture is used to irrigate crops, including alfalfa which is in turn used as fodder for sheep and buffalo. The detailed water budgets of these schemes have not been elaborated, nor are there rigorous economic analyses. These need to be studied.

At the watershed level, pond aquaculture can also play a significant role in reducing erosion and helping to regulate surface water run-off (Pullin and Prein, 1995). This wider role of pond aquaculture as an integral part of resilient and productive small farming systems is increasingly recognised, especially in parts of Africa where adoption of aquaculture has only recently begun to expand as the social and economic factors governing farmers decisions have been better understood and addressed. However more quantitative data on the soil and water implications of expanded aquaculture are needed.

\section{Discussion}

Freshwater fisheries provide an essential supply of animal protein to large parts of the developing world. At national, community and family levels these systems are critically important in sustaining food security. As demand for freshwater increases, and as further investments are made to exploit the hydropower potential of many of the large rivers, the economic and social importance of these resources needs to be recognised and water management policies and practices designed in consequence. To achieve this however a much stronger understanding of the relationship between water levels and flow and the productivity and value of these fisheries is required. In recent years there has been remarkably little detailed study of such systems and a number of methodological challenges need to be overcome if robust methodologies that can be applied in a range of river systems are to be developed. Efforts to address these need to be intensified.

Similarly more systematic study of ways to harness the potential for fish production in irrigation systems is required. The yields reported from irrigation systems, and the sizeable net benefits obtained by farmers integrating fish culture with rice are of great potential importance. However this needs to be examined in more countries and communities, and the dissemination of positive results strengthened. As for river fisheries, great care is needed to ensure that work on these systems is socially relevant and that a sustainable management regime is identified. The recent work by WorldFish in Bangladesh and Vietnam indicates successful approaches to this (Dey and Prein 2003, 2004a and 2004b).

Faced with a continuing large gap between global supply and demand for fish protein, and especially critical shortages in some regions, notably Sub-Saharan Africa (Delgado et al., 2003), aquaculture is widely regarded as having a critical role in meeting global and regional food requirements over the next 20 years. As discussed here available evidence indicates that aquaculture can be a water efficient means of food production, while also bringing wider resource management benefits. However more rigorous analysis of the water requirements of different forms of aquaculture need to be pursued and ways to reduce water demand further identified. Work to achieve this should be undertaken in a range of environmental and climatic conditions.

\section{Acknowledgements}

We are grateful to Eric Baran for Fig.1 and, Gamal El Naggar and Robin Welcomme for comments on an earlier version of this paper. 


\section{References}

Arthington AH, Baran E, Brown CA, Dugan P, Halls AS, King JM, Minte-Vera CV, Tharme RE \& Welcomme RL (in press). Water Requirements of Floodplain Rivers and Fisheries: Existing DecisionSupport Tools and Pathways for Development. WorldFish Center, Penang, Malaysia.

Baran E and Cain J (2001). Ecological and modelling approach to flood-fish relationships in the Mekong river basin. Contribution to the National Workshop on Ecological and Environmental Modelling (ECOMOD 2001), 3-4 September 2001, Universiti Sains Malaysia, Penang, Malaysia. 6 pp

Baran E., Van Zalinge N., Ngor Peng Bun, Baird I.G., Coates D. 2001a. Fish resource and hydrobiological modelling approaches in the Mekong Basin. ICLARM, Penang, Malaysia and the Mekong River Commission Secretariat, Phnom Penh, Cambodia. 60 ppBaran E., Van Zalinge N., Ngor Peng Bun 2001b. Analysis of the Cambodian Bagnet ("dai") fishery data. ICLARM, Penang, Malaysia, Mekong River Commission Secretariat and Department of Fisheries, Phnom Penh, Cambodia. 62 pp.

Baran E, Van Zalinge N, Ngor Peng Bun (2001b). Floods, floodplains and fish production in the Mekong basin: present and past trends. Contribution to the Asian Wetlands Symposium 2001, 27-30 August 2001, Penang, Malaysia. 11 pp.

Bondari K, Treadgill ED and Bender JA (1983). Tilapia culture in conjunction with irrigation and urban farming. Pp 484-493 in Proceedings, International Symposium on Tilapa in Aquaculture. Comps. L. Fishelson and Z. Yaron. Israel, Tel Aviv University Press.

Brummett R (1997). Farming fish to save water. Bioscience 47 (7): 402.

Brummett R (2002). Realizing the potential of integrated aquaculture: evidence from Malawi. In: Norman Uphoff (ed). Agro-ecological innovations- Increasing Food Production with participatory Development. Erthscan Publications Ltd. London. Sterling. VA

Coates D (1984). A survey of the fish fauna of Sudanese irrigation systems with reference to the use of fishes in the management of ecological problems (the control of aquatic weeds, malaria and infective schistosomiasis). Fish Management, 15 (3): 81-96.

Costa-Pierce BA (1998). Constraints to the sustainability of cage aquaculture for resettlement from hydropower dams in Asia: an Indonesian case study. Journal of Environment and Development 7: 333-368.

Costa-Pierce BA and Effendi P (1988). Sewage fish cages of Kota Cianjur, Indonesia. NAGA; The ICLARM Quarterly 11(2): 7-9.

Cruz EM Al-Ameeri AA Al-Ahmed AK and Ridha MT (2000). Partial budget analysis of Nile Tilapia Oreochromis niloticus cultured within an existing agricultural farm in Kuwait. Asian Fisheries Science 13: 297-305.

Demaine $\mathrm{H}$ and Halwart M (2001). An overview of rice-based small-scale aquaculture. In: Utilizing different aquatic resources for livelihoods in Asia- A resource book. International Institute of Rural Reconstruction, Cavite, The Philippines 416 pp.

Delgado C., Nikolas W., Rosegrant M. W., Meijer S. and Ahmed M (2003) Fish to 2020- Supply and Demand in Changing Global Markets. International Food Policy Research Institute, Washington D. C. and WorldFish Center Penang Malaysia 226 pp.

De Silva SS (2001). Reservoir fisheries: broad strategies for enhancing yields. In SS De Silva (ed) Reservoir and culture-based fisheries: Biology and Management. Canberra: Australian Centre for International Research 7 -15

De Silva SS and Amarasinghe UW (1996). Reservoir fisheries in Asia. Pp189-216 in Perspectives in Asian Fisheries, a volume to commemorate the $10^{\text {th }}$ anniversary of the Asian Fisheries Society. DeSilva, S.S. Ed. Manila, Asia Fisheries Society.

D`Silva AM and Maughan OE (1994). Multiple use of water: integration of fish culture and tree growing. Agroforestry Systems 26:1-7.

D`Silva AM and Maughan OE (1996). Optimum density of Red Tilapia Oreochromis mossambicus x O. urolepis hornorum in a pulsed-flow culture system. Journal of the World Aquaculture Society 27 (1): 126-129.

Dey MM and Prein M (2003). Participatory research at landscape level: floodprone ecosystems in Bangladesh and Vietnam. pp. 223-225 In B. Pound, S.S. Snapp, C. McDougall, and A. Braun (eds.) 
Managing natural resources for sustainable livelihoods: uniting science and participation. Earthscan and IDRC, London. 252 p. http://www.prgaprogram.org/download/chatham99_case_studies.pdf

Dey MM and Prein M (2004a). Increasing and sustaining the productivity of fish and rice in the floodprone ecosystems in South and Southeast Asia. Final Report to IFAD. WorldFish Center, Penang, 94 p. + Appendices.

Dey MM and Prein M (2004b) Feasibility of community based fish culture in seasonally flooded rice fields in Bangladesh and Vietnam. Aquaculture Economics and Management 8(3/4) (in press).

Fernando CH Gurgel JJS and Moyo NAG (1998). A global review of reservoir fisheries. Internationale revue der Gesamten Hydrobiologie, 83:31-42.

Fernando, CH and Halwart M (2000). Possibilities for the integration of fish farming into irrigation systems. Fisheries Management and Ecology 7: 45-54.

GAFRD (2000). General Authority for Fish Resources Development (GAFRD), Fisheries Statistics Yearbook 1999. Cairo, Egypt.

Guttman H (1999). Rice field fisheries - a resource for Cambodia. NAGA the ICLARM quarterly. 22 (2): 11-15.

Haight BA (1994). Report of the technical Consultation on the enhancement of small water body fisheries in southern Africa. Harare, Zimbabwe, 25-29 January 1993. Harare, FAO. 35pp.

Halwart M (1998). Trends in rice-fish farming. FAO Aquaculture Newsletter 18:3-11.

Haylor GS (1994). Fish production from engineered waters in developing countries. In: J.E. Muir and R.J. Roberts (eds) Recent Advances in Aquaculture. Oxford: Blackwell Scientific Publications, pp. 1103.

Ishak MM (1982). Aquaculture Egypt - Development of fish farming in Egypt. IDRC Rep.1. (phase 1).

Ishak MM (1986). Development of fish farming in Egypt (cage and pen culture). Report no.4 (phase II) Institute of Oceanography and Fisheries and IDRC, Cairo. 101pp.

Lae R (1992). Influence de l'hdrologie sur les pêcheries du delta central du Niger de 1966 à 1989 . Aquat. Living Resour., 5: 115-126.

Marr JC (1986). Twenty year fishery development plan for Bangladesh. FAO Marr Report.

McMurty MR, Sanders DC, Cure JD and Hudson RG (1997). Effects of biofilter/culture tank volume ratios on productivity of a recirculating fish/vegetable co-culture system. Journal of Applied Aquaculture 7:33-51.

Miranda LE (1999). A typology of fisheries in large reservoirs of the United States. North American Journal of Fishery Management, 19: 536-50.

Moreau J and DeSilva SS (1991). Predictive fish yield models for lakes and reservoirs of the Philippines, Sri Lanka and Thailand, FAO Fisheries technical Paper 319, Rome, Italy.

Oi S (1997). Introduction to modernization of irrigation schemes. FAO RAP Water Report 12: 9-16.

Petrere M (1996). Fisheries in large tropical reservoirs in South America, in Lakes and Reservoirs: Research and Management, 2: 111-133.

Pimentel D, Houser J, Preiss E, White O, Fang H, Mesnick L, Barsky T, Tariche S, Schreck J and Alpert S (1997). Water resources: agriculture, the environment and society. Bioscience 47 (2): 97-106.

Prein M (2002). Integration of aquaculture into crop-animal systems in Asia. Agricultural Systems 71 (2002) $127-146$.

Pullin RSV and Prein M (1995). Fishponds facilitate natural resources management on small-scale farms in tropical developing countries. Pp 169-186 in J-J. Symoens and J-C. Micha (Eds.) The management of integrated freshwater agro-piscicultural ecosystems in tropical areas. Brussels, CTA.

Redding TA and Midlen AB (1990). Fish production in irrigation canals: a review. FAO Fisheries Technical Paper 317, 111pp.

Ruddle K and Zhong G (1988). Integrated Agriculture-Aquaculture in South China. Cambridge: Cambridge University Press, 173pp.

Seckler D Amarasinghe U Molden D de Silva R and Barker R (1998). World water demand and supply, 1990-2025: Scenarios and issues. Research Report 19. Colombo, Sri Lanka: International Water Management Institute. 
Sugunan VV (1997). Fisheries management of small water bodies in seven countries in Africa, Asia and Latin America. FAO Fisheries Circular 933, Food and Agriculture Organization of the United Nations $149 \mathrm{pp}$

Sugunan VV (2001). Status of culture-based fisheries in small reservoirs in India. In SS De Silva (ed) Reservoir and culture-based fisheries: Biology and Management. Canberra: Australian Centre for International Research $7-15$.

Sverdrup-Jensen S (1999). Policy issues deriving from the impact of fisheries on food security and the environment in developing countries, p. 73-91. In M. Ahmed, C. Delgado, S. Sverdrup-Jensen and R.A.V. Santos (eds.) Fisheries policy research in developing countries: issues, priorities and needs. ICLARM Conf. Proc. 60, 112 pp.

Sverdrup-Jensen (2002). Fisheries in the Lower Mekong basin: status and perspectives. MRC Technical Paper No.6. Mekong River Commission, Phnom Penh 103 pp

Swingle HS (1972). Relationship of the Thai fish culture program to the production of fish in the lower Mekong area. SEADAG Mekong development Seminar.

Thilsted SH Roos N and Hassan N (1997). The role of small indigenous species in food nutrition security in Bangladesh. Paper presented at the International Consultation on Fisheries Policy Research in Developing Countries, Hirtshals, Denmark, 2-5 June 1997.

Thilsted SH and Roos N (1999). Policy issues on fisheries in relation to food and nutrition security, p.6169. In M. Ahmed, C. Delgado, S. Sverdrup-Jensen and R.A.V. Santos (eds.) Fisheries policy research in developing countries: issues, priorities and needs. ICLARM Conf. Proc. 60, 112pp.

Teutcher T (2001). Fish Utilisation pp125-133 in Welcomme, R.L. Inland Fisheries; ecology and management. Fishing New Books, Blackwell Science, Oxford. 358pp.

Van Zalinge N, Nao Thuok, Touch Seang Tana, Deap Loeung (2000). Where there is water, there is fish? Cambodian fisheries issues in a Mekong River Basin perspective. p. 37-48. In M. Ahmed and P. Hirsch (eds.) Common property in the Mekong: issues of sustainability and subsistence. ICLARM Studies and Reviews 26, 67 pp.

Welcomme RL (1985). River fisheries. FAO fisheries technical paper No.262. 330 pp.

Welcomme RL (2001). Inland Fisheries; ecology and management. Fishing New Books, Blackwell Science, Oxford. 358pp.

Williams M (1999). Foreword in Middendorp, H.A.J., P.M. Thompson and R.S. Pomeroy, Editors. Sustainable inland fisheries management in Bangladesh. ICLARM Conf. Proc.58, 280 pp. 